JURNAL BASICEDU

Research \& Learning in Elementary Education

https://jbasic.org/index.php/basicedu

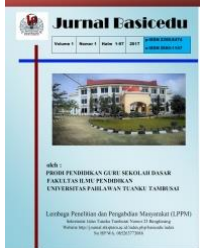

\title{
PENERAPAN MODEL PEMBELAJARAN KOOPERATIF TIPE STAD UNTUK MENINGKATKAN HASIL BELAJAR SISWA DI SEKOLAH DASAR
}

\author{
Jesmita ${ }^{1}$ \\ Universitas Kristen Satya Wacana, Jawa Tengah, Indonesia ${ }^{1}$ \\ Email : 292015118@ student.uksw.edu $^{1}$
}

\begin{abstract}
Abstrak
Penelitian ini berangkat dari kondisi siswa kelas 4 SDN Wates 01 hasil belajarnya masih rendah melalui observasi dan wawancara dengan guru kelas. Berdasarkan latar belakang tersebut tujuan penelitian ini adalah mendeskripsikan langkah-langkah model pembelajaran Kooperatif Tipe STAD (Students teams achievement divisions) untuk meningkatkan hasil belajar. Penelitian ini menggunakan jenis penelitian tindakan kelas dan berlangsung dalam 2 siklus. Teknik pengumpulan data dalam penelitian ini menggunakan tes dan non tes. Hasil dari penelitian ini dengan menggunakan model pembelajaran Kooperatif Tipe STAD (Students teams achievement divisions) dapat meningkatkan hasil belajar siswa dalam pembelajaran tematik terpadu yang diperoleh melalui penelitian yang sudah dilaksanakan. Hal ini dapat dilihat melalui tindakan siklus I nilai rata-rata sebesar 75\% dengan frekuensi siswa yang tuntas 12 dengan persentase 46,15\% dan frekuensi siswa tidak tuntas ada 14 dengan persentase 53,85 \%. Sedangkan pada Siklus II hasil belajar siswa mengalami peningkatan dengan rata-rata 82,1, frekuensi siswa yang tuntas ada 19 dengan persentase 73,07\%, sedangkan yang tidak tuntas ada 7 dengan presentase $26,93 \%$.
\end{abstract}

\section{Kata Kunci: Kooperatif Tipe STAD, Hasil Belajar, Tematik}

\begin{abstract}
This study was conducted due to the learning result of fourth grade in SDN Wates 01 that was still considered as low as been found from observations and interviews with the home teacher. Therefore, this research aims to describe the steps of Cooperative STAD (Students Teams Achievement Divisions) type in order to improve the learning result. This research applied class action research type and was conducted in two cycles. The data was collected through test and non-test. The result showed that STAD (Students Teams Achievement Divisions) could increase the students' learning result in integrated thematic subject. It could be seen through the action cycle I with the average value was $75 \%$ that consists of the frequency of students who had completed was 12 with the percentage of $46.15 \%$ and the frequency of students who had not completed was 14 with the percentage of $53.85 \%$. In cycle II, the students' learning result was increased with the average of 82.1 and the frequency of students who had competed was 19 with the percentage of $73.07 \%$. Meanwhile, the frequency of students who had not completed was 7 with the percentage of $26.9 \%$
\end{abstract}

Keywords: Students Teams Achievement Divisions, Chievement of Learning, Thematic

@ Jurnal Basicedu Prodi PGSD FIP UPTT 2019

$\triangle$ Corresponding author:

Address : Jawah Tengah

Email : mithasamongilailai@gmail.com

ISSN 2580-3735 (Media Cetak)

Phone

ISSN 2580-1147 (Media Online) 
2138 Penerapan model pembelajaran kooperatif tipe STAD untuk meningkatkan hasil belajar siswa di sekolah dasar - Jesmita

\section{PENDAHULUAN}

Pendidikan di Indonesia sedang menyesuaikan kurikulum terbaru ialah kurikulum 2013 yang sudah ditetapkan melalui kementerian pendidikan dan kebudayaan pada tahun 2013. Kurikulum tahun 2013 merupakan penyempurnaan dari Kurikulum Berbasis Kompetensi dan Kurikulum Tingkat Satuan Pendidikan (KTSP). Pemberlakuan kurikulum 2013 untuk SD/MI secara nasional mulai tahun pembelajaran 20142015. Konsekuensi utama pemberlakuan kurikulum 2013 tersebut diantara pada cara mensinergikan pendekatan model, dan standar proses pembelajaran, serta cara menyusun dan melakukan penilaian Mawardi, (2014:107-108).

Pembelajaran tematik diartikan sebagai kegiatan belajar yang disusun dengan memperhatikan tema-tema tertentu. Tema dapat ditinjau dari mata pelajaran dan memiliki sub tema-sub tema di dalamnya. Terjalinnya hubungan antar tema secara terpadu, akan menfasilitasi siswa untuk aktif terlibat dalam proses pembelajaran dan mendorong siswa untuk memahami tema yang telah dipelajari berdasarkan pengalaman dan mengaitkannya dengan situasi nyata. Hal tersebut belajar tematik didefinisikan sebagai suatu kegiatan belajar yang dirancang sekitar ide pokok dan melibatkan beberapa bidang mata pelajaran yang berkaitan dengan tema. Pembelajaran tematik sebagai suatu konsep yang memadukan pendekatan pembelajaran yang di dalamnya terdapat konsep-konsep yang terhubung baik secara intern maupun antar mata pelajaran.

Menurut Rusma dalam paparan Fitri Indriani (2016:4) pembelajaran tematik terpadu merupakan suatu sistem pembelajaran yang memungkinkan siswa, baik secara individu maupun secara holistik, bermakna, dan autentik. Sedangkan Menurut Mawardi (2013:110) ciri-ciri pembelajaran tematik terpadu, diantaranya adalah a) Berpusat pada anak; b) Memberikan pengalaman langsung pada anak; c) Pemisahan antar mata pelajaran yang terkandung menjadi satu kesatuan dan diaplikasikan dalam satu pertemuan; d) Mengadakan beberapa pelajaran dalam satu pelaksanaan kegiatan belajar mengajar; e) Bersifat fleksibel; f) Nilai dapat berubah sesuai dengan keinginan dan kondisi siswa.

Menurut Fitri (2015:89), mengatakan pembelajaran tematik meliputi aliran progresivisme, kontrutisme, dan humanisme. Menekan bagi siswa untuk memiliki sikap kreativitas dalam bekerja kelompok. IPA merupakan ilmu yang mempelajari kejadian di alam semesta dari usaha manusia dengan melewati sebuah observasi, menggunakan prosedur dan menjelaskan penalaran untuk mendapatkan kesimpulan. Pelajaran ilmu pengetahuan alam merupakan suatu proses belajar mengajar yang dibangun oleh guru untuk mengembangkan kreativitas berpikir siswa yang dapat meningkatkan kemampuan berpikir siswa, serta dapat meningkatkan kemampuan mengkontruksi pengetahuan baru sebagai upaya meningkatkan penguasaan yang baik terhadap materi ilmu pengetahuan alam (Rudi Pujiono 2017:1). Setiawati Sulis (2016) Pembelajaran Bahasa Indonesia di SD dilaksanakan secara terpadu. Pelajaran bahasa indonesia diarahkan untuk meningkatkan kemampuan peserta didik untuk berkomunikasi dalam bahasa indonesia dengan baik dan benar, baik secara lisan mau pun tulisan serta menumbuhkan apresiasi terhadap sastra manusia Indonesia Setiawati Sulis. 2016

Berdasarkan hasil pengamatan dan wawancara pada proses pembelajaran tematik di SD Negeri Wates 01 sudah menerapkan yang namanya kurikulum baru yaitu kurikulum 2013 akan tetapi ada beberapan yang belum diterapkan dalam kriteria kurikulum 2013 pada pembelajaran tematik belum menggunakan model pembelajaran. Metode pembelajaran yang digunakan guru dikelas 


\section{Penerapan model pembelajaran kooperatif tipe STAD untuk meningkatkan hasil belajar siswa di sekolah dasar - Jesmita}

4 masih ceramah dan berpusat dengan guru mendengarkan penjelasan guru serta mengerjakan soal-soal yang diberikan oleh guru sehingga peserta didik cenderung tidak bersemangat dan akhirnya berpengaruh pada rendahnya prestasi belajar yang diperoleh siswa hasil berlajar yang diperoleh kurang memuaskan dan pembelajaran kurang bermakna bagi siswa. Data yang diperoleh dari hasil belajar IPA, IPS dan Bahasa Indonesia siswa kelas 4 di SD Negeri Wates 01 dalam ranah pengetahuan dikatakan bahwa 4 dari 10 siswa belum mencapai KKM yang ditentukan 75 dengan rata-rata siswa mendapat nilai 65 . Hasil tes yang diperoleh siswa sebanyak 4 siswa $(65 \%)$ mendapat nilai dibawa KKM 70, sedangkan 6 siswa $(25 \%)$ mendapat nilai diatas 75. jadi, hasil dari data menunjukkan bahwa hasil belajar siswa kelas 4 di SD Negeri Wates 01 belum menunjukkan hasil yang maksimal.

Menurut Robert E. Slavin, "The main idea behind Students Team - Achievment Divisions adalah untuk memotivasi peserta didik supaya dapat saling mendukung dan membantu satu sama lain dalam menguasai kemampuan yang diajarkan guru”. Sedangkan menurut Triono (2010;67) mengatakan bahwa model pembelajaran kooperatif tipe STAD merupakan salah satu tipe dari model pembelajaran kooperatif dengan menggunakan kelompok-kelompok kecil dengan jumlah tiap anggota kelompok 4-5 orang siswa secara heterogen. Sehingga dapat simpulkan bahwa model pembelajaran kooperatif adalah merupakan suatu model pengajaran dimana siswa belajar secara berkelompok yang memiliki tingkat kemampuan yang berbeda-beda. Oleh sebab itu mata pelajaran tematik di tingkat SD dengan menggunakan model pembelajaran kooperatif tipe stad harapannya dapat meningkatkan hasil belajar.

Menurut Menurut Ni L. Gd. Marheni, I Wyn. Sujana dan D.B. Kt Ngr. Semara Putra (2013:2) terdapat beberapa alasan diterapkan model pembelajaran kooperatif tipe Students Teams-Achievement Division (STAD) dalam pembelajaran IPS. Siswa ditempatkan dalam kelompok-kelompok belajar yang beranggotakan empat sampai lima orang yang heterogen baik dari jenis kelamin, kemampuan kognitif, afektif, maupun kemampuan psikomotor dan kepada siswa secara individu atau kelompok yang meraih prestasi tinggi atau memperoleh skor sempurna diberi penghargaan.

Sedangkan menurut Slavin dalam Ni Made Sunilawati (2113) model pembelajaran kooperatif tipe stad adalah dicirikan dengan struktur tugas, tujuan, dan penghargaan termasuk juga dalam penerapannya dua atau lebih individu salaing ketergantungan satu sama lain untuk mencapai satu penghargaan yang sama.

Menurut Triono (2010:66) ada beberapa langkah-langkah pembelajaran kooperatif antara lain ialah menyampaikan tujuan dan motivasi, menyajikan informasi, mengorganisasikan kedalam kelompok kooperatif, membimbing kelompok bekerja dan belajar, evaluasi, dan memberikan penghargaan.

fase-fase menurut U. Nugroho dkk (2009:109) menyampaikan tujuan dan memotivasi siswa, menyajikan informasi, mengoeganisasi siswa kedalam kelompok belajar, membantu kerja kelompok dalam belajar, evaluasi, dan pemberian penghargaan.

Menurut Susanto, (2013:5) hasil belajar diartikan sebagai keberhasilan siswa dalam memahami pembelajaran di sekolah yang ditunjukkan dengan skor sesuai dengan hasil tes pada mata pelajaran tertentu. Kalau Slameto (2010:20) menyampaikan belajar adalah suatu proses usaha yang dilakukan seseorang untuk memperoleh suatu perubahan tingkah laku yang baru secara keseluruhan, sebagai hasil pengalamannya sendiri dalam interaksi dengan lingkungan. 
2140 Penerapan model pembelajaran kooperatif tipe STAD untuk meningkatkan hasil belajar siswa di sekolah dasar - Jesmita

Sesuai uraian tersebut maka dapat disimpulkan bahwa hasil belajar merupakan hasil yang diperoleh siswa setelah terjadinya proses pembelajaran yang ditunjukkan dengan nilai tes yang diberikan oleh guru setiap selesai memberikan materi pelajaran pada satu pokok bahasan.

\section{METODE}

Menurut Hanifah (2014:12), mempaparkan bahwa Penelitian tindakan kelas adalah penelitian bersifat reflektif untuk memperbaiki dan meningkatkan pelaksanaan pembelajaran di kelas bersifat reflektif secara personal. Sedangkan menurut Wina Sanjaya (2013:149), PTK merupakan proses pengkajian masalah pembelajaran di kelas melalui refleksi diri dan upaya untuk memecahkan dengan cara melakukan berbagai jenis tindakan yang terencana dalam situasi nyata serta menganalisis setiap pengaruh dari tindakan tersebut.

Variabel penelitian ini terdiri dari varibel $\mathrm{X}$ yaitu variabel bebas dan variabel $\mathrm{Y}$ yaitu variabel terikat. Tujuannya untuk meningkatkan hasil belajar pembelajaran tematik siswa SDN Wates 01. Teknik tes dalam penelitian menggunakan soal evaluasi pihan ganda diberikan pada siklus 1 dan 2 untuk mengukur hasil belajar siswa dalam pembelajaran tematik dengan menggunakan model pembelajaran kooperatif tipe stad. Analisis data dalam penelitian tindakan kelas bahwa data kuantitatif dianalisis dengan teknik analisis distribusi komparasi dengan menentukan rata-rata hasil terlebih dahulu. Bukan hanya data kuantitatif tetapi dengan penelitian kualitatif juga. Dalam menentukan data kualitatif dapat dianalisis dengan deskriptif. Tingkat Kesukaran dan Fungsi Pengecoh. Tingkat kesukaran soal merupakan angka yang menunjukkan keterampilan siswa mengerjakan butir soal dengan benar (Slameto,

\section{HASIL DAN PEMBAHASAN}

Penelitian pada kegiatan siklus I di laksanakan dalam 3 kali pertemuan, dengan menggunakan langka-langkah model pembelajaran kooperatif tipe STAD. Penelitian ini melakukan observasi dan wawancara untuk mengetahui kondisi awal atau bisa disebut perencanaan, tindakan, observasi, dan tindakan.

Guru menujukkan gambar kepada peserta didik materi tentang berbagai jenis pekerjaan. setelah itu siswa mengidentifikasi masalah lewat kelompok yang sudah di bagi dalam jumalah siswa terdiri dari 5 orang. Dari kerja kelompok siswa dapat belajar bersama dengan teman-temannya sehingga bisa menyelesaikan tugas dengan baik. peningkatan pada siklus I dan siklus II pada pelajaran tematik tema 4 Jenis-jenis Pekerjaan sub tema 1 berbagai jenis pekerjaan. Pembelajaran tematik bukan hanya mempelajari tentang keterampilan tetapi dapat meningkatkan hasil belajar siswa.

Pada penelitian pertama terdapat satu variabel yaitu hasil belajar siswa yang dapat ditingkatkan dengan menggunakan model pembelajaran Kooperatif Tipe STAD. Hasil belajar merupakan kemampuan siswa untuk memecahkan masalah dengan solusi yang sudah ditemukan dalam proses belajar mengajar serta siswa melalui tugas yang dikerjakan oleh siswa. Berikut adalah gambar tentang hasil belajar siswa dalam siklus I:

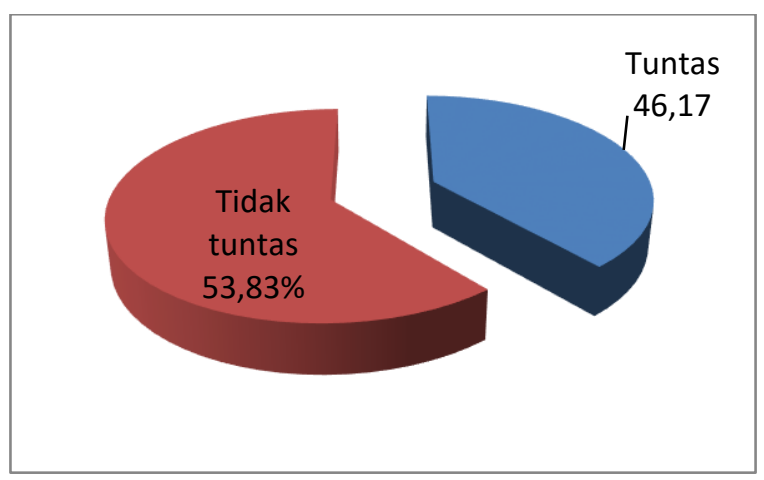

Gambar 1

Hasil belajar siklus I 2010). 
2141 Penerapan model pembelajaran kooperatif tipe STAD untuk meningkatkan hasil belajar siswa di sekolah dasar - Jesmita

Jika dilihat dari gambar diatas ketuntasan hasil belajar siswa pada siklus I sebanyak 46,17\% atau 12 siswa. Sedangkan hasil belajar siswa yang tidak tuntas sebanyak 53,85\% atau 14 siswa. Jadi, dari 26 siswa yang hanya tuntas diatas KKM sebanyak 12 anak. sehingga dapat dikatakan masih banyak siswa yang mempeoleh nilai dibawah KKm. Oleh sebab itu, peneliti akan melakukan siklus II.

Penelitian tindakan pada siklus II dilakukan untuk memperbaiki hasil dari siklus I. Dimana dari guru harus benar-benar mempersiapkan dengan membuat rencana pelaksanaan pembelajaran, mengkundusifkan kelas, lebih memperhatikan siswa dalam menyelesaikan tugasnya bersama kelompok.

Kegiatan pada siklus II melakukan langkahlangkah model pembelajaran kooperatif tipe STAD dengan baik. Sehingga sesudah menyelesaikan siklus II hasil belajar peserta didik terjadi peningkatan. Berikut gambar hasil belajar pada siklus II.

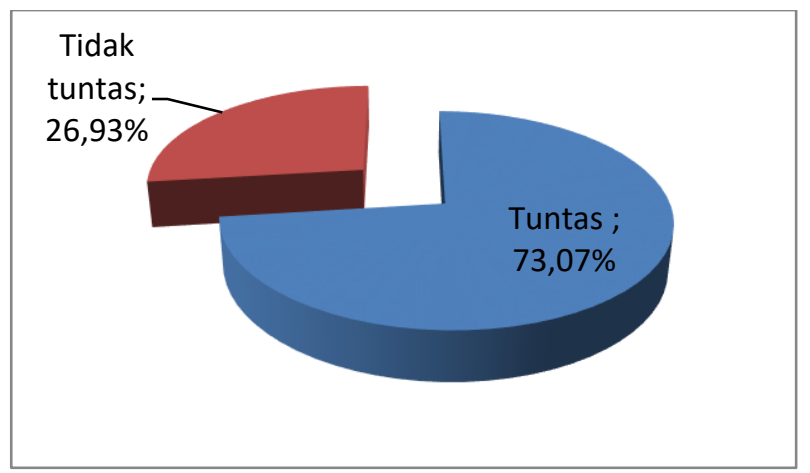

Gambar 2

Hasil Belajar siklus II

Jika dilihat dari gambar diatas ketuntasan hasil belajar siswa pada siklus II sebanyak 73,07\% atau 19 siswa. Sedangkan hasil belajar siswa yang tidak tuntas sebanyak $26,93 \%$ atau 7 siswa. Jadi, dari 26 siswa yang tuntas diatas KKM sebanyak 19 anak. Lewat penelitian yang sudah dilakukan dapat dikatakan bahwa terjadinya peningkatan hasil belajar siswa pada setiap siklus. Berikut data Repitulasi distribusi hasil belajar siswa:
Tabel 1. Repitulati Distribusi Hasil Belajar Siklus I dan Siklus II SDN Wates 01

\begin{tabular}{|l|l|l|l|l|l|}
\hline \multirow{2}{*}{ No } & \multirow{2}{*}{ Nilai } & \multicolumn{2}{|l|}{ Siklus I } & \multicolumn{2}{l|}{ Siklus II } \\
\cline { 3 - 6 } & & F & $\%$ & F & $\%$ \\
\hline 1 & Tuntas & 12 & 46,17 & 19 & 73,07 \\
\hline 2 & $\begin{array}{l}\text { Tidak } \\
\text { tuntas }\end{array}$ & 14 & 53,83 & 7 & 26,93 \\
\hline \multicolumn{2}{|l|}{ Jumlah } & 36 & 100 & 26 & 100 \\
\hline
\end{tabular}

Berdasarkan tabel repitulasi distribusi hasil belajar pembelajaran tematik dapat dilihat pada peningkatan dari siklus I hanya 12 siswa yang tuntas atau 46,17\% dari 26 anak dan yang nilai tidak tuntas ada 14 siswa atau 53,83\%. Tapi bagian siklus II hasil belajar peserta didik mengalami peningkatan dengan nilai yang tuntas ada 19 siswa atau $73,07 \%$ dan yang tidak tuntas ada 7 siswa atau $26,93 \%$ dari 26 siswa.

Penerapan model pembelajaran kooperatif tipe STAD dengan sintak ialah menyampaikan tujuan dan motivasi, menyajikan informasi, mengorganisasikan kedalam kelompok, membimbing kelompok bekerja dan belajar, evaluasi, dan memberikan penghargaan sudah dilakukan dengan sesuai langkah-langkah yang ada. Hal ini terlihat pada repitulasi deskripsi hasil belajar siswa pada siklus I dan Siklus II yang ada di atas atau dapat lihat siklus I hanya 12 siswa yang tuntas atau 46,17\% dari 26 anak dan yang nilai tidak tuntas ada 14 siswa atau 53,83\%. Tapi bagian siklus II hasil belajar peserta didik mengalami peningkatan dengan nilai yang tuntas ada 19 siswa atau $73,07 \%$ dan yang tidak tuntas ada 7 siswa atau 26,93\% dari 26 siswa. Jadi, dari repitulasi deskriptif hasil belajar siswa dapat di simpulkan bahwa adanya perbedaan hasil nilai dengan model pembelajaran kooperatif tipe STAD meningkatnya hasil belajar siswa. seperti penelitian hasil belajaran dari Hasil penelitian dengan menggunakan model pembelajaran kooperatif tipe STAD sejalan dengan hasil penelitian peningkatan hasil belajar yang 
2142 Penerapan model pembelajaran kooperatif tipe STAD untuk meningkatkan hasil belajar siswa di sekolah dasar - Jesmita

dilakukan oleh Fidarto Muhammad. yaitu terjadinya peningkatan dalam hasil belajar siklus I dan siklus II, Ni L. Gd. Marheni, I Wyn. Surjana, dan D.B. Kt Ngr. Semara Putra. 2010 yaitu terjadinya peningkatan hasil belajar siswa pada siklus I dan siklus II, Andianis Triwiratih dan Julianto. 2014 terjadinya peningkatan dalan hasil belajar siswa terlihat dari siklus I dan siklus II, U. Nugroho dkk 2009 melakukan penelitian tentang hasil belajar terjadi peningkatan dengan menggunakan model pembelajaran kooperatif tipe STAD dapat dilihat dari siklus I dan siklus II, dan Fidarto Muhammad. 2019 terjadinya peningkatan hasil belajar siswa dapat dilihat dari siklus I dan siklus II. Menyatakan bahwa terjadi peningkatan dalam hal belajar siswa.

\section{SIMPULAN}

Pada penelitian yang sudah dilaksanakan berdasarkan hasil pembahasan, maka dapat disimpulkan bahwa menggunakan model pembelajaran kooperatif tipe STAD dapat meningkatkan hasil belajar siswa kelas 4 SDN Wates 01 dalam pembelajaran tematik dengan mengunakan langkah-langkah pembelajaran yang meliputi menyampaikan tujuan dan memotivasi siswa, menyajikan informasi, mengorganisasikan siswa ke kelompok belajar, membantu kerja kelompok dalam belaja, evaluasi, dan pemberian penghargaan. Dapat dilihat dari data peningkatan hasil belajar siklus I berjumlah siswa 12 atau 46,15 $\%$ dari 26 siswa yang mencapai KKM 70 sedangkan siklus II adanya peningkatan 19 atau 84,62 \% siswa mencapai KKM 70 dari 26 siswa.

Berdasarkan kesimpulan diatas maka model pembelajaran kooperatif tipe STAD disarankan untuk dipakai di dalam pembelajaran tematik di SD karena dapat meningkatkan hasil belajar siswa

\section{DAFTAR PUSTAKA}

Andianis Triwiratih dan Julianto. 2014. Penggunaan Model Pembelajaran Kooperatif Tipe STAD untuk Meningkatkan Hasil Belajar IPA di Sekolah Dasar. JPGSD

Fidarto Muhammad. 2019. Penerapan Model Pembelajaran Student Team Achievement Division (STAD) Untuk Meningkatkan Hasil Belajar PKn Pada Materi Berorganisasi Di Kelas V SD Negeri 09 Kediri Barat. Jurnal Ilmiah Pembelajaran Sekolah Dasar

Hanifah Nani. (2014). Perbandingan Tingkat Kesukaran, Daya Pembeda Butir Soal dan Rehabilitas Tes Bentuk Pilihan Ganda dan pilihan Ganda Asosiasi Mata Pelajaran Ekonomi. Jurnal SOSIO E-KONS.

Kemendikbud. 2014. Permendikbud Nomor 24 Tahun 2016 Tentang Kompetensi Inti dan Kompetensi Dasar. Menteri Pendidikan dan Kebudayaan Republik Indonesia: Jakarta.

Majid, A. 2009. Perencanaan Pembelajaran. Bandung. Remaja Rosdakarya.

2013. Strategi Pembelajaran. Bandung. Remaja Rosdakarya.

Mawardi. 2014. Pemberlakuan Kurikulum SD/MI Tahun 2013 dan Implikasinya Terhadap Upaya Memperbaiki Proses Pembelajaran Melalui PTK. Scholaria, 4 (3) 108.

Ni L. Gd. Marheni, I Wyn. Surjana, dan D.B. Kt Ngr. Semara Putra. 2010. Penerapan Model Pembelajaran Kooperatif Tipe STAD untuk Meningkatkan Kearifan dan Hasil Belajar IPS Kelas V SD N. 8 Padang Sambian Denpasar. Jurnal

Peraturan Menteri Pendidikan dan Kebudayaan No.23 Tahun 2016 Tentang Standar Penilaian Pendidikan

Permendikbud. 2016. Permendikbud Nomor 21 Tahun 2016 Tentang Standar Isi Pendidikan Dasar dan Menengah. Jakarta: Menteri Pendidikan dan Kebudayaan Republik Indonesia.

Suprijono. (2009). Model Pembelajaran. Jakarta: Reneka Cipta

Slavin. (2005). Cooperative Learning: Teori, Riset, dan Praktik. Bandung: Nusa Media 
2143 Penerapan model pembelajaran kooperatif tipe STAD untuk meningkatkan hasil belajar siswa di sekolah dasar - Jesmita

Suharsimi Arikunto, S. (2007). Penelitian Tindakan Kelas. Jakarta: PT. Bumi Aksara.

Sugiyono. (2012). Metode Penelitian Pendidikan Pendekatan Kuantitatif, Kualitatif dan R\&D. Bandung: Alfabeta

Susanto, Ahmad. 2013. Teori Belajar Dan Pembelajaran Di Sekolah Dasar. Jakarta: Kencana.

Slameto. 2014. Permasalahan-Permasalahan Terkait dengan Propesi Guru SD. Jurnal Scholaria

2015. Rasional dan Elemen Perubahan Kurikulum 2013. Jurnal Scholaria.

2015. Implementasi Penelitian Tindakan Kelas. Jurnal Shcolaria

Setiawati Sulis. 2016. Penggunaan Kamus Bahasa Indonesia (KBBI) dalam Pembelajaran Kosakata Baku dan Tidak Baku Pada Siswa Kelas IV SD. Jurnal Gramatika.

Trianto. (2010). Mengembangkan Model Pembelajaran Tematik. Jakarta: PT. Prestasi Pustakaraya.

U. Nugroho dkk 2009 Penerapan Pembelajaran Kooperatif Tipe STAD Berorientasi Kerampilan Proses. Jurnal Pendidikan Fisika Indonesia 5 108-112 (109) 